\title{
Production of Sugar From Sweet Sorghum Stems with Hydrolysis Method Using Trichoderma viride
}

\author{
Melycorianda Hubi Ndapamuri ${ }^{1}$, Maria Marina Herawati ${ }^{1 *}$, V. Irene Meitiniarti ${ }^{2}$ \\ ${ }^{1}$ Faculty of Agriculture and Business, Satya Wacana Christian University, Indonesia \\ ${ }^{2}$ Faculty of Biology, Satya Wacana Christian University, Indonesia \\ *Corresponding Author: maria.marina@uksw.edu
}

Submitted: 2020-08-30. Revised: 2020-11-11. Accepted: 2021-03-25

\begin{abstract}
Sorghum stem bagasse waste is one of the materials with high cellulose content. It can be utilized in glucose production through enzymatic hydrolysis of cellulose by Trichoderma viride. This study aims to determine sorghum stem bagasse's potential in producing glucose, assessing the time and concentration of sorghum stem bagasse in the hydrolysis process to produce glucose optimally and following SNI. Hydrolysis was carried out using a concentration of 5\%, $8 \%$, and $11 \%$ sorghum stem bagasse for 10 , 15 , and 20 days. The results showed that sorghum stem bagasse waste could produce glucose with an average glucose yield of $10.09 \%$ to $24.40 \%$. There is a tendency that increasing substrate concentration and hydrolysis time will increase the yield of liquid glucose. The treatment of 5\% concentration of sorghum stem bagasse with a long hydrolysis time of 10 days can produce the highest liquid glucose, namely $24.40 \%$ with total dissolved solids of $7.40 \%$ Brix, the ash content of $0.26 \%$, but $47.54 \%$ water content has not met SNI standards.
\end{abstract}

Key words: bagasse of sorghum; glucose; hydrolysis; Trichoderma viride

How to Cite: Ndapamuri, M., Herawati, M., \& Meitiniarti, V. (2021). Production of Sugar From Sweet Sorghum Stems with Hydrolysis Method Using Trichoderma viride. Biosaintifika: Journal of Biology \& Biology Education, 13(1), 121-127.

DOI: http://dx.doi.org/10.15294/biosaintifika.v13i1.25954

\section{INTRODUCTION}

Sorghum (Sorghum bicolor, L.) is a C4 plant that can grow in areas with hot and dry conditions so that it is more tolerant of drought and salinity stress than other cereals (Menezes et al., 2014; Rahayu et al., 2012). Sorghum seeds can be used to substitute wheat flour; fresh stems, and leaves as animal feed; while the root can be used as a bioherbicide and herbal medicine (Suminar et al., 2017). Most Indonesia regions, especially East Nusa Tenggara, are currently developing sorghum as a non-rice food as a support of food diversification program (Tnunay et al., 2019). Balai Pengkaji Teknologi Pertanian Bali (2019) utilizes sap from sorghum stems as a sweetener. So that sorghum plants have great opportunities as multifunctional plants that can be developed industrially.

Sorghum stem bagasse is pulp from pressing or secreting sap from the sorghum stem (Pabendon et al., 2012). The content of sorghum stem bagasse based on the dry weight is in the form of cellulose $(58.23 \%)$, hemicellulose (25.42\%), and lignin (14.95\%) (Thanapimmetha et al., 2011). In contrast, sugarcane bagasse content has $40-50 \%$ cellulose, hemicellulose 23-35\%, and lignin 18-24\% (Mandal \& Chakrabarty, 2011). This sorghum stem bagasse's potential must be utilized maximally to produce products that have high economic value, one of which is to be converted into reducing sugar. The cellulose content in sorghum stem bagasse can be converted into glucose through the hydrolysis process using cellulase enzymes.

Cellulase enzyme is a collection of several enzymes that work together to hydrolyze cellulose. Cellulase enzymes hydrolyze cellulose to sugar, including cellobiose (disaccharides composed of two molecules of $\beta$ - $(1,4)$ linked glucose) and glucose (Lynd et al., 2002). Cellulase breaks the $\beta$-glycoside bond, which connects to sugar constituent units of cellulose. Based on structural characteristics, cellulase is classified into three main types of enzymatic activity, namely endoglucanase, $\beta$ glucosidase, and exoglucanase. Lynd et al (2002) further explained that endoglucanase works on cellulose fiber regions with low crystallinity. The enzyme will break down cellulose and randomly form free chain ends. Exoglucanase further degrades the molecule by removing cellobiose units from free chain ends. The enzyme $\beta-1,4$ glucosidase hydrolyzes cellobiose to glucose.

One of the microorganisms that can produce cellulase enzymes is the fungus Trichoderma viride. This fungus can produce cellulase enzymes and can hydrolyze cellulose from various raw materials into glucose. Sulistyani and Setyowati (2000) reported that glucose production from Imperata sp. hydrolysis by $T$. viride fungi could be increased by $13.4 \mathrm{mg} / \mathrm{ml}$ with a hydrolysis duration of 14 days. Saparianti et al (2012) reported that glucose production from the hydrolysis of sugarcane bagasse by $T$. viride ( 6 days 
by $10 \% \mathrm{v} / \mathrm{v})$ reached $13.44 \%$ of $8 \%$ sugarcane baggasse and 15 days of hydrolysis. Besides, the use of microorganisms in the production process has advantages because of lower production costs and products free from unwanted ions or heavy metals (Saparianti et al., 2012).

The study on $T$. viride as a hydrolyzer of cellulose primarily contained in sweet sorghum stems bagasse has never been done before. Therefore it is necessary to assess sorghum stem bagasse concentration and the hydrolysis time that can produce the highest glucose. Permanasari et al (2018) stated that enzymes and concentrations of essential substances in glucose production, at low concentrations, the reaction rate is shallow. However, this reaction rate will increase with the increase of the substrate concentration. Sorghum bagasse has a higher cellulose content than sugarcane bagasse; in the research of Saparianti et al. (2012), the substrate concentration and the length of time for hydrolysis are essential to note. Because the substrate concentration and $T$. viride influence the enzymatic reaction's speed, the high cellulose content in sorghum stem bagasse will produce higher glucose than in sugarcane. The study's reasult were expected to meet the Indonesian National Standard or Standar Nasional Indonesia (SNI) 01-2978-1992 concerning glucose syrup. This SNI follows the standard of glucose syrup made from starch. Since the food and beverage industry's material needs to meet quality standards, the researchers choose several vital variables such as ash content, moisture content, and reducing sugar as the standard.

This study aimed to determine the potential of sweet sorghum stem bagasse to produce glucose through hydrolysis by $T$. viride. The resulting glucose is expected to be included in the SNI criteria, including ash content, moisture content, and reducing sugar. The study's results can provide additional information and knowledge about the development of glucose production technology by utilizing waste of sweet sorghum stem bagasse which is hydrolyzed with cellulase enzymes from $T$. viride.

\section{METHODS}

The research design in this study used a Randomized Block Design (RBD) factorially arranged. The treatment in this study consisted of two factors, each factor consisting of three levels. "A" factor was the concentration of sorghum bagasse flour (by volume of distilled water) with 3 levels, namely $5 \%\left(\mathrm{~S}_{1}\right), 8 \%\left(\mathrm{~S}_{2}\right)$, and $11 \%\left(\mathrm{~S}_{3}\right)$. While the " $\mathrm{B}$ " factor is the hydrolysis time with 3 levels, namely 10 days $\left(\mathrm{H}_{1}\right), 15$ days $\left(\mathrm{H}_{2}\right)$, and 20 days $\left(\mathrm{H}_{3}\right)$. 9 treatment combinations were obtained from these two factors, and each treatment was repeated 3 times
(27 experiment units). The data obtained were analyzed by Analysis of Variance (ANOVA). A significant difference between treatments then proceed with Duncan's Multiple Test (DMRT) using a $5 \%$ confidence interval.

\section{Procedures}

Following a method by Saparianti et al., 2012 with modification. Sweet sorghum stem bagasse were sorted, taken properly, were not attacked by red spots, fungi, and other disorders. Then stored and squeezed with the help of water until the level of sweetness was lost. Furthermore, the bagasse was cut into pieces size $\pm 2 \mathrm{~cm}$ and dried in an oven with a temperature of $50^{\circ} \mathrm{C}$ for 12 hours. After drying, the bagasse was milled in two cups to produce a fine sorghum bagasse powder. The first stage uses a grinder for 2 times, after that it is refined using a blender for 2 times. The sorghum bagasse powder obtained was then sieved using a 100 mesh sieve.

T. viride from pure culture was rejuvenated in the MEA medium. T. viride culture was inserted with sterile needles into an Erlenmeyer containing MEA medium and incubated for 6 days at room temperature. The 6 days old T. viride culture was harvested using physiological saline solution and shaken with small marbles. After that, it was suspended into $11 \mathrm{ml}$ of $0.01 \%$ sterile peptone solution, where $1 \mathrm{ml}$ was to count the number of molds and the other $10 \mathrm{ml}$ was for the hydrolysis process.

Glucose production began by making hydrolysis media. The media was made with a composition of 90 $\mathrm{ml}$ distilled water, sorghum bagasse powder according to treatment $(5 \%, 8 \%$, and $11 \%), 0.05 \mathrm{ml}$ acetic acid $0.2 \mathrm{M}$, acetate buffer $0.2 \mathrm{M}$ to $\mathrm{pH} 5$, and 12 grams of urea. Then the media was sterilized in an autoclave at $121^{\circ} \mathrm{C}$ for 15 minutes and cooled to room temperature. Then the media was inoculated with 10 $\mathrm{ml}$. viride and incubated in an shaker incubator with a rotation speed of $120 \mathrm{rpm}$ for 10, 15, and 20 days (according to the treatment) at room temperature. At the end of hydrolysis, the media was centrifuged to obtain a hydraulic result that was ready to be analyzed. The analysis used in this study was water content analysis, ash content analysis, analysis of reducing sugar levels, and total dissolved solids (\% Brix).

\section{RESULT AND DISCUSSION}

Hydrolysis is the chemical breakdown process of a molecule because of the binding of water to produce smaller molecules. This process is expressed by the reaction equation $\mathrm{AB}+\mathrm{H}_{2} \mathrm{O} \rightleftharpoons \mathrm{AH}+\mathrm{BOH}$. $\mathrm{AB}$ is a bond of a substance, when water is added, a chemical 
reaction occurs, which causes the bonding of the substance to be broken (Speight, 2017). This reaction causes water to be an indicator that influences the process of cellulose hydrolysis. The moisture content analysis results in the hydrolysis of sorghum stem bagasse with concentrations of $5 \%, 8 \%$, and $11 \%$ for 10,15 , and 20 days can be seen in table 1 .

Table 1. Average moisture content (\%) in the hydrolysis of sorghum stem bagasse

\begin{tabular}{lccccc}
\hline \multirow{2}{*}{ Treatment } & \multicolumn{5}{c}{ Moisture Content (\%) at Hydrolysis Time } \\
\hline \multirow{3}{*}{ Sorghum concentration } & & 10 days & 15 days & 20 days & Average \\
\cline { 2 - 6 } & $5 \%$ & 47.54 & 44.26 & 43.90 & $45.23 \mathrm{a}$ \\
\cline { 2 - 6 } Average & $11 \%$ & 45.09 & 43.51 & 41.80 & $43.46 \mathrm{a}$ \\
\cline { 2 - 6 } & $46.36 \mathrm{p}$ & 43.89 & 43.92 & $44.09 \mathrm{a}$ \\
\hline
\end{tabular}

Note: Numbers followed by different notations show significant differences between the components of the DMRT test results. The letters a, b, c are for the sorghum concentration notation, while $\mathrm{p}, \mathrm{q}, \mathrm{r}$ are for the hydrolysis time notation.

The results of moisture content analysis in table 1 show that the treatment of 10 days of hydrolysis time with different sorghum bagasse concentrations shows a difference, but the longer the hydrolysis time and sorghum bagasse concentration used did not show a sigificant difference.

This decrease in moisture content in the hydrolysis results shows that during the hydrolysis process the $\mathrm{OH}$ binding occurs and followed by the formation of new compounds (Speight, 2017). The more OH ions are bound, the higher the resulting product and the lower the moisture content in the solution. This study's hydrolysis process used a cellulase enzyme catalyst derived from $T$. viride to accelerate the reaction rate. Cellulase enzymes can break down polysaccharide (cellulose) bonds into monosaccharides (sugar molecules) (Mackul'ak et al., 2010). T. viride uses cellulose a source of carbon needed for its activity (producing cellulose enzymes) to synthesize metabolite products in the form of glucose monomers.
The study's hydrolysis results were analyzed for total dissolved solids to show that the decomposition of sorghum stem bagasse celluse by $T$. viride. Total dissolved solids is the amount of concentration of the solution dissolved in a solution. In this research, the dissolved solution can be sugar as the main product and other ingredients. The instrument used to measure is a hand refractometer that works by utilizing light that fills a solution. Light entering the solution has different wavelength depending on the density in a solution. The value of the refraction of light produces the amount of substance dissolved in a solution with a scale unit of \% Brix. If the dissolved particle concentration is increased, the number of particles that can interact with light is higher and results in a high Brix value that is read (Hidayanto \& Rofiq, 2010). The analysis of total dissolved solids on the hydrolysis results with sorghum concentrations of $5 \%, 8 \%$, and $11 \%$ after 10,15 , and 20 days can be seen in table 2.

Table 2. Average total dissolved solids (\%) in the hydrolysis of sorghum stem bagasse

\begin{tabular}{lccccc}
\hline \multirow{2}{*}{ Treatment } & \multicolumn{5}{c}{ Total Dissolved Solids (\%) at Hydrolysis Time } \\
& & 10 days & 15 days & 20 days & Average \\
\hline \multirow{2}{*}{ Sorghum concentration } & $5 \%$ & 7.40 & 7.67 & 7.90 & $7.66 \mathrm{a}$ \\
\cline { 2 - 6 } & $8 \%$ & 7.67 & 7.35 & 7.53 & $7.52 \mathrm{a}$ \\
\cline { 2 - 6 } Average & 7.57 & 7.50 & 8.03 & $7.70 \mathrm{a}$ \\
\cline { 2 - 6 } & $7.55 \mathrm{p}$ & $7.51 \mathrm{p}$ & $7.82 \mathrm{p}$ & \\
\hline
\end{tabular}

Note: Numbers followed by different notations show significant differences between the components of the DMRT test results. The letters $\mathrm{a}, \mathrm{b}, \mathrm{c}$ are for the sorghum concentration notation, while $\mathrm{p}, \mathrm{q}, \mathrm{r}$ are for the hydrolysis time notation.

The analysis of total dissolved solids in table 2 show that the concentrations of $5 \%, 8 \%$, and $11 \%$ with a hydrolysis time of 10,15 , and 20 days did not significantly affect the total dissolved solids. However, the total dissolved solids in the results of this study of all treatments produced total dissolved solids of about $7.35 \%-8.03 \%$ Brix, higher than the results of research Saparianti et al (2012) using sugarcane bagasse $(6.47 \%$, Brix). These results 
indicate that sorghum stem bagasse has a higher potential than sugarcane bagasse to produce sugar.

During an overhaul of material, the process can produce a higher total dissolved solid (Bayu et al., 2017). The number of dissolved solids can be used to interpret the amount of sugar in the material, in this case, the sugar needed is the result of cellulose hydrolysis. These studies results are consistent with the opinion of Goldstein et al. (2015), which stated that the total dissolved solids can be used to interpret the sugar content in a source that contains the actual percentage of sugar. In hydrolysis results, dissolved solids are from the emission group and amorphous cellulose raw materials, which are not hydrolyzed and dissolved in the medium. Amorphous cellulose forms a formless part in the cellulose chain with a more tenuous structure. Amorphous cellulose has a strong effect on total dissolved solids because it can make thin suspensions (Whittenberger \& Nutting in Chokhyun, 1999 as cited in Saparianti et al., 2012).

The total solids obtained in table 2 indicates the presence of substances dissolved in the hydrolysis solution. Therefore, reducing sugar produced is the main product in cellulose hydrolysis. Reducing sugars are glucose and other sugars that can reduce oxidizing compounds, by measuring the amount of oxidizing compounds reduced by a solution, it can be done to estimate the sugar concentration (Leustean et al., 2010). The analysis result of reducing sugars on the hydrolysis results with sorghum concentrations of $5 \%, 8 \%$, and $11 \%$ after 10,15 , and 20 days can be seen in table 3.

Table 3. Average reducing sugars (\%) in the hydrolysis of sorghum stem bagasse

\begin{tabular}{lccccc}
\hline \multirow{2}{*}{ Treatment } & \multicolumn{5}{c}{ Reducing Sugars Content (\%) at Hydrolysis Time } \\
\hline \multirow{2}{*}{ Sorghum concentratio } & $5 \%$ & 24.40 & 23.55 & 20.60 & $22.85 \mathrm{a}$ \\
\cline { 2 - 6 } & $8 \%$ & 14.03 & 14.37 & 14.29 & $14.23 \mathrm{~b}$ \\
\cline { 2 - 6 } Average & $11 \%$ & 10.70 & 10.81 & 10.09 & $10.54 \mathrm{c}$ \\
\cline { 2 - 6 } & & $16.38 \mathrm{p}$ & $16.24 \mathrm{p}$ & $15.00 \mathrm{p}$ & \\
\hline
\end{tabular}

Note: Numbers followed by different notations show significant differences between the components of the DMRT test results. The letters $\mathrm{a}, \mathrm{b}, \mathrm{c}$ are for the sorghum concentration notation, while $\mathrm{p}, \mathrm{q}, \mathrm{r}$ are for the hydrolysis time notation.

The results of the analysis of reducing sugars are in table 3. showed that the sorghum concentration treatment showed a difference. However, the length of time for hydrolysis did not show a significant difference in the analysis results of reducing sugars. When compared with the results of the analysis of moisture content in table 1 and dissolved solids in table 2 , it can be said that the results of the analysis of reducing sugars obtained have increased by decreasing the moisture content and the higher the amount of dissolved solids. The sugar analysis results with the highest value in this study were found in the combination of 5\% sorghum concentration with 10 days of hydrolysis time, namely $24.40 \%$. Compared with glucose from the hydrolysis of reeds and sugarcane bagasse, the highest production was only $13.44 \%$ at a concentration of $8 \%$ with a hydrolysis time of 15 days (Saparianti et al, 2012). The hydrolysis process of sorghum stem bagasse in this study only requires more minor cellulose sources with a faster hydrolysis time, which can produce higher sugars than other ingredients.

There was no significant difference in the analysis of reducing sugars after the longer hydrolysis time could be affected by the life phase of $T$. viride during the hydrolysis process. Lailah et al (2017) reported that $T$. viride undergoes a stationary phase because the cell growth process stops, but the metabolic process continues so that the resulting product increases. Lailah et al. (2017) stated that reducing sugar levels increased on the $6^{\text {th }}$ day and decreased on the $9^{\text {th }}$ day. Sulistyani and Setyowati (2000) reported that glucose production from the hydrolysis of Imperata, sp by $T$. viride fungus could be increased by the hydrolysis duration of 14 days. Saparianti et al. (2012) also reported that hydrolysis of $8 \%$ sugarcane bagasse by Trichoderma viride with 15 days of hydrolysis duration produced the best glucose.

Other solids dissolved in the hydrolysis result can also be minerals contained in the ingredient. Therefore, it is necessary to analyze the ash content, which approximation mineral content in a material through the ashing result (inorganic residual combustion products) of a material (Yusak, 2004). The analysis of ash content on the hydrolysis results with sorghum concentrations of $5 \%, 8 \%$, and $11 \%$ after 10,15 , and 20 days of incubation can be seen in Table 4. 
Table 4. Average ash content (\%) in the hydrolysis results of sorghum stem bagasse

\begin{tabular}{lccccc}
\hline \multirow{2}{*}{ Treatment } & \multicolumn{5}{c}{ Ash Content (\%) at Hydrolysis Time } \\
& & 10 days & 15 days & 20 days & Average \\
\hline \multirow{2}{*}{ Sorghum concentration } & $5 \%$ & 0.26 & 0.28 & 0.24 & $0.26 \mathrm{a}$ \\
\cline { 2 - 6 } & $8 \%$ & 0.30 & 0.24 & 0.25 & $0.27 \mathrm{a}$ \\
\cline { 2 - 6 } Average & $11 \%$ & 0.49 & 0.46 & 0.37 & $0.44 \mathrm{a}$ \\
\cline { 2 - 6 } & & $0.35 \mathrm{p}$ & $0.33 \mathrm{p}$ & $0.29 \mathrm{p}$ & \\
\hline
\end{tabular}

Note: Numbers followed by different notations show significant differences between the components of the DMRT test results. The letters a, b, c are for the sorghum concentration notation, while $\mathrm{p}, \mathrm{q}, \mathrm{r}$ are for the hydrolysis time notation.

The ash content analysis results in table 4 show that the treatment of sorghum concentrations of 5\%, $8 \%$, and $11 \%$ with a hydrolysis duration of 10,15 , and 20 days did not significantly affect ash content. When compared with the results of the analysis of total dissolved solids in table 2 and reducing sugars in table 3, it can be said that the total amount of dissolved solids is influenced by the amount of ash and reducing sugar in the hydrolysis results.

An increase and decrease in ash content in the hydrolysis results indicate that the hydrolysis process carried out by $T$. viride causes changes in a material. These changes also affect the total amount of dissolved solids and reducing sugars. Cellulase enzymes produced by Trichoderma viridae can convert biomass material (cellulose) into valuable bioproducts such as glucose (Saha, 2004).

The sweet sorghum stem bagasse used in this study is agricultural cellulose waste. It has not been adequately utilized, both as a raw material for the food and beverage industry and other ready-made products. Lumoindong \& Mamuaja (2016) reported that waste containing cellulose is more widely used as food, fuel is used or disposed as a waste. Using $T$. viride service to hydrolyze sorghum bark produced enzymatically can produce valuable and high-quality products. The Indonesian National Standardization Agency has set standards for products commercialized through the SNI 01-2978-1992. Therefore, the quality of sugar from the hydrolysis of sorghum stem bagasse will be compared with the SNI criteria. Based on research done, the quality of the results of the hydrolysis of sorghum stem bagasse based on the value of reducing sugar, total dissolved solids, moisture content, and ash content can be seen in table 5. While table 6 shows the comparison of the best hydrolysis results with SNI.

Table 5. The results of the analysis of reducing sugars, total dissolved solids, moisture content, and ash content in the hydrolysis results of sorghum stem bagasse.

\begin{tabular}{|c|c|c|c|c|}
\hline Treatment & $\begin{array}{c}\text { Reducing Sugar } \\
(\%)\end{array}$ & Total Dissolved Solids (\%) & $\begin{array}{c}\text { Moisture Content } \\
(\%)\end{array}$ & $\begin{array}{l}\text { Ash Content } \\
(\%)\end{array}$ \\
\hline $\begin{array}{l}\text { Sorghum 5\%, hydrolysis time } 10 \\
\text { days }\end{array}$ & $24.40 \mathrm{a}$ & $7.40 \mathrm{a}$ & $47.54 \mathrm{a}$ & $0.26 \mathrm{a}$ \\
\hline $\begin{array}{l}\text { Sorghum } 5 \% \text {, hydrolysis time } 15 \\
\text { days }\end{array}$ & $23.55 \mathrm{a}$ & $7.67 \mathrm{a}$ & $44.26 \mathrm{abc}$ & $0.28 \mathrm{a}$ \\
\hline $\begin{array}{l}\text { Sorghum } 5 \% \text {, hydrolysis time } 20 \\
\text { days }\end{array}$ & $20.60 \mathrm{a}$ & $7.90 \mathrm{a}$ & $43.90 \mathrm{abc}$ & $0.24 \mathrm{a}$ \\
\hline $\begin{array}{l}\text { Sorghum } 8 \% \text {, hydrolysis time } 10 \\
\text { days }\end{array}$ & $14.03 \mathrm{~b}$ & $7.67 \mathrm{a}$ & $45.09 \mathrm{abc}$ & $0.30 \mathrm{a}$ \\
\hline $\begin{array}{l}\text { Sorghum } 8 \% \text {, hydrolysis time } 15 \\
\text { days }\end{array}$ & $14.37 \mathrm{bc}$ & $7.35 \mathrm{a}$ & $43.51 \mathrm{bc}$ & $0.24 \mathrm{a}$ \\
\hline $\begin{array}{l}\text { Sorghum } 8 \% \text {, hydrolysis time } 20 \\
\text { days }\end{array}$ & $14.29 \mathrm{bc}$ & $7.53 \mathrm{a}$ & $41.80 \mathrm{c}$ & $0.25 \mathrm{a}$ \\
\hline $\begin{array}{l}\text { Sorghum } 11 \% \text {, hydrolysis time } \\
10 \text { days }\end{array}$ & $10.70 \mathrm{bc}$ & $7.57 \mathrm{a}$ & $46.44 \mathrm{ab}$ & $0.49 \mathrm{a}$ \\
\hline $\begin{array}{l}\text { Sorghum } 11 \% \text {, hydrolysis time } \\
15 \text { days }\end{array}$ & $10.81 \mathrm{bc}$ & $7.50 \mathrm{a}$ & $41.89 \mathrm{c}$ & $0.46 \mathrm{a}$ \\
\hline $\begin{array}{l}\text { Sorghum } 11 \% \text {, hydrolysis time } \\
20 \text { days }\end{array}$ & $10.09 \mathrm{c}$ & $8.03 \mathrm{a}$ & $43.92 \mathrm{abc}$ & $0.37 \mathrm{a}$ \\
\hline
\end{tabular}

Note: Numbers followed by different notations show significant differences between the components of the DMRT test results. 
Table 6. Comparison between the result of sorghum 5\% hydrolysis with hydrolysis time 10 days with SNI criteria

\begin{tabular}{llc}
\hline Character & SNI* & Sorghum 5\%, hydrolysis time 10 days ** \\
\hline Moisture (\%) & Maxsimum 20 & 45.09 \\
Ash (\%) & Minimum 1 & 0.30 \\
Reducing sugars (\%) & Minimum 30 & 41.80 \\
\hline \multicolumn{2}{r}{ Source :* SNI glucose syrup (1992); ** Primary Data (2019) }
\end{tabular}

Based on table 5, the researcher choose $5 \%$ sorghum concentration treatment with a hydrolysis time of 10 days as a treatment with the highest reducing sugar content. However, the water content value was not following SNI (Table 6). When compared with the hypothesis that has been taken, namely the concentration of sorghum stem bagasse $8 \%$ with a hydrolysis time of 15 days can produce the highest glucose, in this study with a minor concentration $(5 \%)$ can produce the highest glucose with a shorter hydrolysis time (10 days).

The production of sugar from sorghum stem bagasse in this study must be calculated for its yield value. The profit or failure of this sugar production business is largely determined by the yield value produced. The greater the yield value obtained, the greater the sugar produced. The percentages of sugar yielded from the bagasse of sorghum and sugarcane are presented in Table 7.

Table 7. The sugar yielded from the hydrolysis of sorghum and sugarcane

\begin{tabular}{ccc}
\hline $\begin{array}{c}\text { Raw } \\
\text { material }\end{array}$ & $\begin{array}{c}\text { Material weight } \\
(\text { gram })\end{array}$ & $\begin{array}{c}\text { Glucose }(\%) \text { per } \\
\mathrm{kg}\end{array}$ \\
\hline Sorghum & 8 & $17.96^{*}$ \\
Sugarcane & 8 & $16.8^{* *}$ \\
\hline Source :*Primary Data $(2019) ; * *$ Saparianti et al. (2012)
\end{tabular}

Table 7 shows that the yield of sugar obtained from hydrolysis of sorghum stem bagasse in this study was higher than bagasse in the study of Saparianti et al. (2012). So it can be said that the yield produced is greatly influenced by the raw materials used. When viewed from an economic standpoint, this sorghum crop can be developed in marginal areas such as NTT. Apart from producing grains that are used as staple food to substitute for rice, sorghum stalks also have the potential to produce sugar.

In further research, it is necessary to analyze physical, chemical, physiognomic, and biological pretreatment before the hydrolysis process. It is also necessary to do further research on the process after hydrolysis, namely heating and evaporation to obtain the water content of sugar according to SNI.

\section{CONCLUSION}

Based on the results of research and discussion presented previously, it can be concluded that sweet sorghum stem bagasse can produce glucose through the hydrolysis process with the help of the enzyme produced by $T$. viride. The concentration of $5 \%$ sorghum stem bagasse with a hydrolysis time of 10 days is the treatment that gives the highest reducing sugar content. The analysis showed that the reducing sugar content was $24.40 \%$, the ash content was $0.26 \%$ and the total dissolved solids was $7.40 \%$. However, the moisture content of $47.54 \%$ does not meet SNI.

\section{REFERENCES}

Balai Pengkaji Teknologi Pertanian Bali. (2019). Pasca Panen dan Pengolahan Nira Sorgum Menjadi Gula Cair. Info Teknologi. http://bali.litbang.pertanian.go.id/ind/index.php/inf o-teknologi/965-pasca-panen-dan-pengolahannira-sorgum-menjadi-gula-cair

Bayu, K. M., Rizqiati, H., \& Nurwantoro. (2017). Analisis Total Padatan Terlarut, Keasaman, Kadar Lemak, dan Tingkat Viskositas pada Kefir Optima dengan Lama Fermentasi yang Berbeda. Jurnal Teknologi Pangan, 1(2), 33-38.

Goldstein, D., \& Mintz, S. (2015). The Oxford companion to sugar and sweets. Oxford University Press.

Hidayanto, E., \& Rofiq, A. (2010). Aplikasi Portable Brix Meter untuk Pengukuran Indeks Bias. Berkala Fisika, 13(4), 113-118-118.

Lailah, R., Syauqi, A., \& Santoso, H. (2017). Aktivitas Jamur Trichoderma viride pada Substrat Pasta Tepung Kulit Buah Rambutan (Nephelium lappaceum). Bioscience-Tropic, 3(2), 1-7.

Leustean, U., Georgescu, L., \& Bahrim, G. (2010). Preliminary study for optimization of enzymatic hydrolysis of waste cellulosic materials. Food Technology, 35(1), 27-33.

Lumoindong, F., \& Mamuaja, C. F. (2016). Produksi Gula Cair dari Limbah Selulosik sebagai Alternatif Pengganti Cairan Infus. J. Ilmu Dan Teknologi Pangan, 4(1), 36-43.

Lynd, L. R., Weimer, P. J., Zyl, W. H. Van, \& Isak, S. (2002). Microbial Cellulose Utilization: 
Fundamentals and Biotechnology Microbial Cellulose Utilization: Fundamentals and Biotechnology Downloaded from http://mmbr.asm.org/ on February 6, 2013 by Indian Institute of Technology Madras. Microbiology and Molecular Biology Reviews, 66(3), 506-577.

Mackulak, T., Prousek, J., Olejníková, P., \& Bodík, I. (2010). The Using Enzymes For Degradition of Cellulose Substrate for the production of Biogas. 37th International Conference of Slovak Society of Chemical Engineering, 1407-1412. https://doi. org/10.1007/s10924-010-0258-0

Mandal, A., \& Chakrabarty, D. (2011). Isolation of nanocellulose from waste sugarcane bagasse (SCB) and its characterization. Carbohydrate Polymers, 86(3), 1291-1299. https://doi.org/ 10.1016/J.CARBPOL.2011.06.030

Menezes, C. B., Ticona-Benavente, C. A., Tardin, F. D., Cardoso, M. J., Bastos, E. A., Nogueira, D. W., Portugal, A. F., Santos, C. V., \& Schaffert, R. E. (2014). Selection indices to identify droughttolerant grain sorghum cultivars. Genetics and Molecular Research, 13(4), 9817-9827. https://doi.org/10.4238/2014.November.27.9

Pabendon, M. B., Sarungallo, R. S., \& Mas'ud, S. (2012). Pemanfaatan Nira Batang, Bagas, dan Biji Sorgum Manis sebagai Bahan Baku Bioetanol. Penelitian Pertanian Tanaman Pangan, 31(3), 180-187. https://doi.org/10.21082/jpptp.v31n3.2012.p\%p

Permanasari, A. R., Yulistiani, F., Purnama, R. W., Widjaja, T., \& Gunawan, S. (2018). The effect of substrate and enzyme concentration on the glucose syrup production from red sorghum starch by enzymatic hydrolysis. IOP Conference Series: Earth and Environmental Science, 160(1). https://doi.org/10.1088/1755-1315/160/1/012002

Rahayu, M., Samanhudi, \& Wartoyo. (2012). Uji Adaptasi Beberapa Varietas Sorgum Manis di Lahan Kering Wilayah Jawa Tengah dan Jawa Timur. Jurnal Caraka Tani, XXVII(1), 53-62.
Saha, B. C. (2004). Lignocellulose Biodegradation and Applications in Biotechnology. January 2004, 2-34. https://doi.org/10.1021/bk-2004-0889.ch001

Sanito, R., Novembrianto, R., \& Pandebesie, E. S. (2015). Kajian penentuan fase pertumbuhan kapang dan bakteri selulolitik pada media pertumbuhan. Prosiding Seminar Nasional Manajemen Teknologi XXII, 1-10.

Saparianti, E., Dewanti, T., \& Dhoni, S. K. (2012). Hidrolisis Ampas Tebu Menjadi Glukosa Cair Oleh Kapang Tricoderma viride. Jurnal Teknologi Pertanian, 5(1), 1-10.

Sudarmadji, S., B. Haryono, \& Suhardi. (1997). Prosedur Analisa Untuk Bahan Makanan dan Pertanian, Liberty, Yogyakarta.

Sulistyani, P., \& T.M. Setyowati. (2000). Optimasi $\mathrm{pH}$ dan Lama Fermentasi untuk Produk Sirup Glukosa dari Alang-alang oleh Trichoderma viride. Jurusan Teknologi Pangan. fakultas Teknologi Industri. UPN "Veteran". Surabaya.

Suminar, R., Suwarto, \& Purnamawati, H. (2017). Determination of N, P, and K Fertilizer Optimum Rates for Sorghum (Sorghum bicolor [L.] Moench). Jurnal Ilmu Pertanian Indonesia, 22(1), 6-12. https://doi.org/10.18343/jipi.22.1.6

Speight, J. (2017). Transformation of inorganic chemicals in the environment in Enviromental Inorganic Chemistry for Engineers. Laramie, Wyoming. CD\&Winc., United Stated.

Standar Nasional Indonesia. (1992). Sirup Glukosa. 01-2978-1992. Jakarta.

Thanapimmetha, A., Vuttibunchon, K., Saisriyoot, M., \& Srinophakun, P. (2011). Chemical and Microbial Hydrolysis of Sweet Sorghum Bagasse for Ethanol Production. Proceedings of the World Renewable Energy Congress - Sweden, 8-13 May, 2011, Linköping, Sweden, 57, 389-396. https://doi.org/10.3384/ecp11057389

Tnunay, I. M. Y., Chikmawati, T., \& Miftahudin. (2019). Morphological Diversity of Local Sorghum Cultival (Sorghum bicolor) of East Nusa Tenggara, Indonesia. Biosaintifika: Journal of Biology \& Biology Education, 11(1), 47-54. 